\title{
Witchcraft narratives
}

in Germany

Rothenburg, 1561-1652

\section{A LISON ROWLANDS}


Witchcraft narratives in Germany 
STUDIES IN EARLY MODERN EUROPEAN HISTORY

This series aims to publish

challenging and innovative research in all areas of early modern continental history.

The editors are committed to encouraging work that engages with current historiographical debates, adopts an interdisciplinary approach, or makes an original contribution to our understanding of the period.

SERIES EDITORS

William G. Naphy and Penny Roberts

EDITORIAL ADVISORY BOARD

Professor N. Z. Davis, Professor Brian Pullan,

Professor Joseph Bergin and

Professor Robert Scribner

Already published in the series

The rise of Richelieu Joseph Bergin

Sodomy in early modern Europe ed. Tom Betteridge

Fear in early modern society eds William Naphy and Penny Roberts

Religion and superstitition in Reformation Europe

Helen Parish and William G. Naphy

Religious choice in the Dutch Republic: the reformation of Arnoldus Buchelus (1565-1641) Judith Pollman

A city in conflict: Troyes during the French wars of religion Penny Roberts 


\section{Witchcraft narratives in Germany}

Rothenburg, 1561-1652

ALISON ROWLANDS

Manchester University Press

Manchester and New York

distributed exclusively in the USA by Palgrave 
Copyright (C) Alison Rowlands 2003

The right of Alison Rowlands to be identified as the author of this work has been asserted by her in accordance with the Copyright, Designs and Patents Act 1988.

Published by Manchester University Press

Oxford Road, Manchester M13 9NR, UK

and Room 400, 175 Fifth Avenue, New York, NY10010, USA

www.manchesteruniversitypress.co.uk

Distributed exclusively in the USA by

Palgrave, 175 Fifth Avenue, New York,

NY10010, USA

Distributed exclusively in Canada by

UBC Press, University of British Columbia, 2029 West Mall,

Vancouver, BC, Canada V6T 1Z2

British Library Cataloguing-in-Publication Data

A catalogue record is available from the British Library

Library of Congress Cataloging-in-Publication Data applied for

ISBN 0719052599 hardback

First published 2003

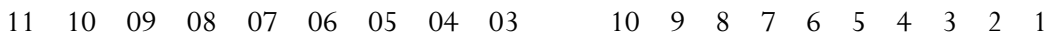

Typeset in Monotype Perpetua with Albertus by Northern Phototypesetting Co Ltd, Bolton Printed in Great Britain

by Biddles Ltd, Guildford and King's Lynn 